\title{
Corporate Governance Practices and Their Impacts on Corporate Risk: Evidence from Sri Lanka.
}

Sameera T.K.G.

Department of Accountancy and Finance, Faculty of Management Studies, Rajarata University of Sri Lanka, Mihintale, Sri Lanka.

tkgsameera@gmail.com

\begin{abstract}
The cost of failure of a single corporate has a fatal impact on the economy. In addition to the macro-economic conditions leading to corporate collapse, management is responsible for developing and implementing a sound system of risk management and internal control in order to avoid such collapses. As a result, discussions on governance and risk have reached an unprecedented level for academics and practitioners. Moreover, risk exposure and management are increasingly becoming the foremost functions of modern business enterprises. However research that integrates corporate governance and risk has been limited. This study examines therefore the impact of corporate governance practices on corporate risk of listed companies in the Colombo Stock Exchange in Sri Lanka. The Board structure, Board Independence and Board procedures were considered as independent variables, whereas, corporate risk as dependent variable. The corporate risk represented the financial, operational and market risks faced by the companies. Furthermore the study used data from a sample of 64 listed companies for 5 years from 2014 to 2018 and employ panel regression to uncover the relationship that exists between these variables. The independent sample t-tests was used to test whether there was a statistically significant difference exist between the corporate governance practices of distress and non-distress companies. The results show that the corporate governance practices of distress companies was significantly lower than that of non-distress companies. The findings of the regression results suggest that Board independence was significantly and negatively impact on corporate risk. However, Board structure and Board procedures have no significant impact on corporate risk. The study therefore, concludes that the increased representation of independent non-executive directors of the board contributed to the significant decrease of corporate risk.
\end{abstract}

Keywords: Corporate Governance, Corporate Risk, Risk Management, Board Independence, Independent Non-Executive Directors

Copyright: () 2020 Sameera T.K.G. This is an open access article distributed under the Creative Commons Attribution License, which permits unrestricted use, distribution, and reproduction in any medium, provided the original work is properly cited.

Correspondence: tkgsameera@gmail.com

ORCID of authors: Sameera T.K.G. - (D) https://orcid.org/0000-0002-0481-7005

DOI: http://doi.org/10.4038/kjm.v9i2.7642 


\section{Introduction}

Corporate governance is a dominant concept in the contemporary business climate in terms of legislation, processes and the administration of contracts between the corporation and shareholders, creditors, employees, vendors, customers and the government. Over the last few years, this concept has been able to attract a great deal of public interest due to its apparent importance for the economic health of companies and society in both developed and developing countries in general. Moreover, the focus of the business community on corporate governance has moved towards internal control and risk management concerns with the recent financial crisis and company failures at the beginning of the millennium (Daelen \& Elst, 2010).

Corporate governance and risk management are interrelated and interdependent (Knight, 2006).Therefore Companies must focus on achieving growth and profitability within the appropriate risk or control limits of corporate governance. According to the Meier (2000), effective management and monitoring of risk-causing factors may contribute to market leadership and increase the growth of a business and the confidence of investors.

Running a business comes with many different types of risk. Some of these potential hazards can destroy a business while others can cause serious damage that can be costly and time-consuming to repair. Despite the risks implicit in doing business risk management can anticipate and prepare for potential risks face by the business. Thus corporate entities believe that the successful operation of any business depends on risk management (Archer, 2002). As pointed out by Doherty (2000), there is evidence in terms of theories (e.g. neoclassical finance theory) that show how value can be generated from the adoption and application of risk management, and how risk can also destroy corporate value. In essence, risk management has now become a global concern in term of value creation and is considered highly important for all forms of organizations around the world.

As Knight stated in his study of "Risk management a journey not a destination" in 2006, the control element is one of the roles of corporate governance, while the risk management process is developing a controlled environment. Moreover such controlled environment makes an organization effective in achieving their objectives within a reasonable degree of risk. Thus broadening of the risk menu has created a challenge for traditional practices of internal controls and is testing the ability to provide adequate oversight through the governance mechanism. Therefore the internal audit and risk management roles have received considerably greater attention and integrated as one of the important parts of the corporate governance code in many countries in the world.

Risk management has traditionally developed as a professional and technical discipline in a number of key areas, such as finance, health and safety, clinical and environmental fields, and so on. However, organizations are increasingly facing a variety of risks including financial, operational, reputational, and regulatory and information risks (Nahar et.al, 2016). Tufano (1996), investigates the impact of corporate governance mechanisms on the level of financial risk for a sample of North American companies. The results of the study emphasize the importance of management risk aversion and executive risk diversification strategies embedded in their corporate risk management incentive contracts. In particular, the study finds that managers who own more 
shareholdings of their firms manage more financial risk while those who hold more stock options tend to manage less financial risk after controlling other variables such as leverage and the degree of degree of business diversification.

In the East Asian financial crisis in 1997, corporate failures, corporate scandals and fraud have been blamed for poor risk management and corporate governance (Mitton, 2002). Lakshan and Wijekoon (2012) argued that poor corporate governance could increase the likelihood of corporate failure even for firms with good financial performance. According to the Kalainathan and Vijayarani, (2014) several corporate scandals taken place in Sri Lanka such as the failure of the Pramukha Savings, Golden Key Credit Card Company and the bankruptcy of Vanic Incorporation, Lanka Marine Services Ltd, Sri Lanka Insurance Corporation etc. have caused great mystification in the stakeholders of the companies. Furthermore, they have stated that these scandals are mainly caused by the failure of corporate governance system. Hence corporate governance is play a vital role of control of such situation by establishing a regulated environment as a result of the risk management process (Knight, 2006).

Beasley et al (2005) examined the extent of implementation of risk management as it relates to corporate governance and other organizational factors. They find that the adoption of risk management is positively related to certain key governance and organizational factors, such as the presence of the Chief Risk Officer, the independence of the Board, the support shown by the CEO and CFO for risk management. Sameera and Wijesena (2018) examine the impact of board structure on credit risk for a sample of the banks listed in Colombo Stock Exchange in Sri Lanka. The results of the study highlight that a negative relationship between board size, board independence, firm size and credit risk which presumes that as a bank increases its board size, board independence, firm size is likely to reduce its credit risk. Moreover results support the resource dependency theory, suggesting that large board could provide valuable expertise, access to resources, high quality advice and is harder for insiders to control, which could help to minimize the credit risk (Sameera \& Wijesena, 2018).

Corporate governance is now encouraging the Boards of Directors to develop more clearly defined risk audit functions. The risk audit function is often an additional responsibility of the audit committee of the board of directors. Since executive directors themselves need to be monitored, the non-executive director chairs the audit committee in order to give it the necessary degree of independence. The Board of Directors is ultimately responsible for the corporate risk of the company, and is accountable to shareholders and other stakeholders. A study in Bangladesh entitled 'Risk governance and performance: a developing country perspective by Naharet.al,(2016) found that risk disclosure, the number of risk committees and the existence of a risk management unit will improve risk management and risk monitoring, which will reflect better performance of the company. Tonello (2009) examined the fact that the boards play an important role in supervision of the entity and they are encouraged to take on entrepreneurial risks and pursue riskbearing strategic opportunities. Corporate governance therefore ensures that all directors and senior executives have a shared understanding of risk, which is the effect of uncertainty on an entity that achieves its strategic objectives and maintains its long-term viability and reputation. In this regards, the managing of risks through a well-organized governance system is an integral part of 
effective business and should be carried out on a systematic and ongoing basis.

However, most of these corporate governance and risk base studies have focused on developed countries. Although there has been significant development in research in developing economies over the last few years, comparatively fewer studies have focused on the context of governance and risk in developing economies. Moreover, in developing economies, the nature of markets, economic uncertainties, and the strength of their institutions, government intervention and the existence of individual bias remain very different from that of developed economies (Rabelo \& Vasconcelos, 2002). Therefore, the results of studies from developed economies might not be accurate in developing economies. And, as the researcher observes, it is difficult to find such work in the context of Sri Lanka. Hence, it was timely and significant to conduct an in depth study to assess the impact of corporate governance practices on corporate risk to find the evidence on the extent to which corporate governance associated with corporate risk.

\section{Literature Review}

Corporate Governance is defined as "a set of relationships between a company's management, its board, its shareholders and other stakeholders. It provides the structure through which the objectives of the company are set, and the means of attaining those objectives and monitoring performance are determined" (OECD Principles of Corporate Governance, 2004, p.11). At the most fundamental level, corporate governance deals with issues arising from the separation of ownership and control.

Agency theory argues that managers focus on self-interest rather than on the needs of shareholders. This suggests the ownership and the management interest may not be aligned, leading to agency costs and internal inefficiencies. Due to the presence of agency costs and internal inefficiencies, agency theory suggests that the aim of corporate governance mechanisms is to provide an assurance that managers can seek and produce the expected outcomes of the shareholders and ultimately reduce the risk of a failure of the particular entity (Jensen \& Meckling, 1996). Failure by agents to act in the interests of principals covers carelessness, inappropriate decisions and frauds. Since such self-interested behavior is common in agents, principals must design organization and controls to minimize the likelihood of its occurrence. Therefore agency theory not only helps to identify situation where agency risk is high but also suggest principles for its reduction through more effective organizational structure. In such effective organizational structure consist of wellorganized governance mechanism and risk management. Thus agency theory provides an invaluable perspective on contemporary risk management issues because it deals with the underlying causes of loss rather than just the symptoms (Sheedy, 2010) and structure of the board of directors of the firm plays a key role in reducing the costs of the agency (Hutchinson \& Gul, 2003).

The growing body of literature on corporate governance has questioned the effectiveness of corporate governance attributes in preventing the occurrence of corporate collapses. It is evident from the studies that major restructuring of operations, change in the strategic decisions, additional capital infusion have been done as resorts to strengthen the survival and rescue the corporate in the distress situation. Financial distress may lead to bankruptcy, liquidation or significant changes in the controls of the corporate settings. When a company is at the verge of collapse similar to financial 
red flags, many corporate governance symptoms could be seen. Top management changes are frequently symptomatic of organizational distress (Daily \& Delton, 1994). Elloumi and Gueyie (2001) examined the corporate governance attributes of financial distressed and healthy firms and concluded that, board of director composition, outside director's ownership and additional directorship held by each outside director, play significant role in influencing the likelihood of financial distress, whereas CEO duality and board size are not associated with firm financial distress probability. Furthermore, in a supplemental analysis, they reported that, as the level of equity ownership of outside directors' increases the likelihood of financial distress decreases. Lee and Yeh (2004) examined the correlation between corporate governance (CG) and financial distress in Taiwan. The main findings of their study were firms with weak CG are vulnerable to economic downturns and the probability of falling into financial distress increases.

In 1932 Berle and Means laid the foundations for studies on corporate governance and risk concepts. Their argument was based on the fact that those who legally owned companies have been separated from their control. Corporate governance and risk management must therefore be established in order to ensure the presence of systems and institutions that guide the way in which companies are governed to reduce the risk of business failure and the misuse of financial resources. Rosen and Zenios (2001) notes that corporate governance is necessary for efficient risk management, and that no risk management aspect can be accomplished without compliance with corporate governance. Ballou (2005) also stated that, in order to conceptualize the relationship between shareholders, top management, the board of directors, and stakeholders, organizations must comply with the rules, regulations and standards of listing requirements for corporate governance and risk management.

Terry, Chris and Phillip (2012) examined the relationships between selected aspects of corporate governance and risk of UK listed companies. They found that financial risk-taking is lower in boards that are small in size, that is, fewer than eight directors, when testing the formal board structures. Further they highlights the proportion of non-executive directors and the existence of risk committees were found to have no significant impact on corporate risk and financial risk-taking was found to be lower where the board of directors was significantly higher than that of non-executives.

Companies face risks at many different levels and in many layers, both inside and outside the business. They are business risk, operational risk, market risk, financial risk and legal risks etc. Therefore, risk management systems, must be able to cope with all these different types of risks (Daelen \& Elst, 2010). Minton, Taillard and Williamson (2010) investigated how risk taking and performance of financial firms in a crisis situation is related to board independence and financial expertise of the board. Their results show that board independence and financial expertise of the board is negatively related to performance in the crisis situation. In contrast to Minton, Taillard and Williamson (2010), Erkens, Hung and Matos (2010) investigated the relation between corporate governance and the performance of financial firms during credit crisis of 2007/2008. They used an international sample of 296 financial firms from 30 countries. They found that firms with more independent boards and higher institutional ownership experienced worse stock returns in the crisis. They argued that, prior to the 
crisis, firms with higher institutional ownership took more risk, resulting in larger shareholder losses during the crisis period. In addition, firms with more independent boards raised more equity capital during the crisis, leading to a transfer of wealth from existing shareholders to debt holders.

Corporate governance should therefore ensure that risks are understood, managed and communicated where appropriate. For this purpose, the board of directors of the companies must have appropriate mechanisms to reward business success and risk management (OECD, 2014). In the event that boards fail to meet these requirements, their businesses will be left open to significant risk management failures that are more extreme when exposed to abnormal economic cycle periods such as periods of crisis.

Based on these empiric evidence, the present study found that there were potentially few sets of board attributes that could be effectively performing on risk. They were structural characteristics such as board composition and CEO duality; director-specific characteristics such as board independence and board procedures which consist of, the conduct of board meetings, existent of the nomination committee, performance appraisal procedure and provisions of appropriate and timely information to board. In the study it is hypothesized that these three contributing elements of board effectiveness may help to explain certain aspects of corporate risk, such as financial risk, operating risk and market risk. However the effectiveness of boards operating on risk can be expected to vary across boards due to different structures, director characteristics and board processes. In the following section, empirical hypotheses are formulated to show the relationship between the corporate risk and the identified attributes of the corporate governance.

\section{Hypothesis Development}

\section{Distress and Non- Distress}

When the business of a firm declines to the point that it cannot fulfill its financial obligations, the firm is said to have entered into a state of financial distress (Baldwin \& Scott 1983). Therefore the key factor in identifying firms in financial distress is their inability to meet contractual debt obligations. Miglani, Ahmed and Henry (2010) suggested that voluntary adoption of specific corporate governance structures lead to lower levels of financial distress and some corporate governance attributes particularly, board size, board independence, existence of audit committee, are significantly weak in distress firms compared to the healthy firms . Nam and Nam (2004) argued that the establishment of a strong corporate governance structure is ensure the economic health of companies. This indicates that governance, particularly in publicly-listed firms, plays a vital role in determining the survival and growth of businesses. As the sample of the study consists of distress and non-disaster firms which is more representative of the current market situation and impartiality, it is important to determine whether there is a significant difference in corporate governance practices between financial distress companies and non-distress companies in Sri Lanka. Thus the following hypothesis is put forward:

H1: Corporate governance index scores of distress companies are significantly lower than the non-distress companies in Sri Lanka

\section{Board Structure}

The structure of the Board shall include the composition of the Board; the balance of executive and non-executive directors and separation of post chairman and CEO. Overall, the ability of non- 
executive and independent directors to work independently on the board and their contribution towards the board's independent decision-making process are considered. Mathew (2013) found that an increase in board size can significantly reduce the firm risk. Lotfi and Mohammadi (2014) found that there is a negative correlation between risk management and the size of the board. This implies that increasing the board size, lowers the corporate risk. According to Sah and Stiglitz (1991), decision theory suggested that diversified opinions within large groups could lead to a compromise in the final decision. It is therefore more likely that a risky project will be rejected as the investment must be considered good by many directors before it is accepted by the group. Daily and Dolton (1994) claimed that CEO duality increases the likelihood of bankruptcy which implies high risk. Based on these evidences, assume that large boards perform on risk function more efficiently. It is therefore hypothesized that:

H2: Companies with higher corporate governance index scores of board structure are likely to have lower corporate risk

\section{Board Independence}

Outside representation was also proposed as a primary criterion of board effectiveness in the form of nonexecutives sitting on the board. For example, studies by Byrd and Hickman (1992), Rosenstein and Wyatt (1990) and Coles et al. (2001) suggest that greater representation of non-executive directors improves the control and strategic functions of the board of directors. Nonexecutives can reduce excessive risktaking by the executives through activities such as close monitoring. This evidence therefore supports the inverse relationship between the non-executive proportions and the corporate risk. Thus the following hypothesis is put forward:

H3: Companies with higher corporate governance index scores of board independence are likely to have lower corporate risk

\section{Board Procedure}

Board procedures shall consist of the conduct of meetings of the Board of Directors, the existence of the nomination committee, the performance appraisal procedure and the provision of appropriate and timely information to the Board. Frequent discussions between the members of the Board are important for effective decision-making. According to Vafeas (2003), the number of board meetings held annually is related to the firm value determined by the share price. Vafeas (2003) has also shown that increasing the frequency of meetings of the Board of Directors, the performance of the business unit is improved. Johl, Kaur and Cooper (2015) found that there was a negative relationship between the frequency of board meetings and business activities in firms. According to Spira and Bender (2004), the existence of board committees, the quality and the appointment of the director are considered by investors in their investment decisions. The Cadbury Committee (1992) recommended to setting up supervisory committees for appointing directors, making a decision on the remuneration of executive directors and auditing financial statements. They considered the board committees to be an additional control mechanism that increased accountability and safeguarded the interests of shareholders. The third hypothesis was therefore proposed as follows in this study.

H4: Companies with higher corporate governance index scores of board procedures are likely to have lower corporate risk 


\section{Methodology}

The study employed secondary data based on the financial statements of the companies listed in the Colombo Stock Exchange (CSE). Risk is considered as the dependent variable. At present most business decisions are taken solely on the basis of financial consequences (Merna and Al-Thani, 2011). According to the Lajili, (2009) potential impacts of nonfinancial risks such as operational risk, Market risk, government regulation risk etc. are under-estimated and poorly understood. Furthermore same study stated that these risks are not attributed to well-defined risk response plan and strategy followed by the firms to control such types of risks. Business leaders must therefore understand such financial and non-financial risks that business tends to face and the extent of those consequences or losses if the risk materializes. Other than that, investors need some indication of whether the returns on investment meet their minimum returns if the investment is fully exposed to the risks identified. Therefore this study considered three main types risk i.e. financial risk, operating risk and market risk to materialize the corporate risk of the firms.

The financial risk measures relate to corporate liquidity (McNulty, 2012). It typically represents the capacity of the firm to secure additional funds during the time of distress. The finance risk is proxied by the leverage (Total debt/Total Assets). Operating risk is the proxied by the ratio of total assets to sales and represents the firm's ability to generate sales from existing assets. The risk is expected to decrease as this ratio decreases (Platt \& Platt, 2012). Market risk is measured as the book value of common equity to market value of equity. Fama and French (1997) suggest that a higher ratio of the book value of common equity to the market value of equity (BE/ME) indicates a higher market risk. As this ratio increases, indicating a relatively lower market assessment and a higher market risk, the probability of bankruptcy is also expected to increase (Chan \& Chen, 1991).

Corporate governance was considered as the independent variable. Based on the Conceptualization, the variables that are treated as potential determinants of board effectiveness for risk was: Board Structure (BS), Board Independence (BI) and Board Procedures (BP). The relative levels of compliance of corporate governance were assessed on the basis of Corporate Governance Index (CGI) (Appendix A ) which was constructed based on the Code of Best Practice on Corporate Governance 2012 and 2017, section 7.10 of Listing Rules of CSE and prior research studies (Manawaduge, 2012, Nam \& Nam, 2004, Balasubramanian, Black \& Khanna ,2010, Balasubramanian Black \& Khanna., 2009). Manifestly, there is judgment involved on which elements to include and equal weight has been given for each element. Further the elements were captured as nominal data, assigning maximum of one (1) mark for compliance and zero (0) for noncompliance. The detailed index containing all sub-indices is given in Appendix A. Given that the specific governance attributes of the board are not the only factor that influences corporate risk, the size of the firm has been incorporated as controls as suggested in previous studies. Most of the previous studies have measured the size of the firm by using the natural logarithm of total assets (Battaglia \& Gallo, 2014). Since in larger organizations, more agency cost can be expected, it is more likely that such companies are thoroughly monitored and proper risk management is required, (Carcello, 2005). Therefore, company 
size can be considered as a control variable in this study.

The population for this study comprises firms listed on the Colombo Stock Exchange from 2014 to 2018 . However, the sample was decided after screening the firms which missing information. The sample was selected on the basis of the companies' distressed and nondistress condition, since they were more reflective of the current market situation and impartial. According to Baldwin and Scott (1983), when a firm's business deteriorates to the point where it cannot meet its financial obligations, the firm is said to have entered the state of financial distress. The classification of distress and non-distress was done based on the calculated Altman $\mathrm{Z}$ values of the 168 companies. This process left a final sample of 64 companies which consists of 32 financially distressed and 32 financially healthy companies. Thus, the final sample includes complete 5-year data from 64 companies, which gives 320 firm-year observations. Financial institutions (banks and insurance) were excluded because of their unique economic characteristics as high leverage and the different compliance and regulatory environments under which they operate (Fama \& French, 1992; Nguyen, 2011; Wahla et al. 2012). The listed firms were used due to data availability and reliability.

For empirical analysis, this study used descriptive analysis, correlation, independent sample t-test and regression analysis. Independent sample t-test was performed to provide evidence for whether there is a statistically significant difference exists between the governance variables of distress and non-distress companies. Since the data in panel nature consisting of both time series and cross-sectional data, linear panel regressions were used to determine whether the governance variables are significantly influenced on corporate risk. The panel regression procedure has been considered more appropriate than other regression techniques such as OLS for problems associated with longitudinal data (Hsiao, 2007). Analysis of the panel data can effectively reduce the problem of omitted variable bias (Hsiao, 2007). It can also reduce the problem of multicollinearity among the independent variables. Since panel regression can be estimated as a fixed effect (FE) model, a random effect (RE) model, or a pooled ordinary least square (POLS) model, a number of diagnostic tests have been carried out to select the appropriate model. The F-test results were used to decide between an FE model and a POLS model. Finally the Hausman test was employed to select the appropriate specification between FE model and RE model. Following are the three regression models were developed to test the relationship between corporate risk and governance variables.

\section{Model -I}

$$
\begin{gathered}
\mathrm{FR}_{i t}=\beta_{0 i t}+\beta_{1} \mathrm{BS}_{i t}+\beta_{2} \mathrm{BI}_{i t}+\beta_{3} \mathrm{BP}_{i t}+ \\
\beta_{5} \mathrm{SF}_{i t}+\mathrm{e}_{i t}-(1)
\end{gathered}
$$

\section{Model -II}

$$
\begin{gathered}
\mathrm{OR}_{i t}=\beta_{0 i t}+\beta_{1} \mathrm{BS}_{i t}+\beta_{2} \mathrm{BI}_{i t}+\beta_{3} \mathrm{BP}_{i t}+\beta_{5} \\
\mathrm{SF}_{i t}+\mathrm{e}_{i t}-(2)
\end{gathered}
$$

\section{Model -III}

$$
\begin{gathered}
\mathrm{MR}_{i t}=\beta_{0 i t}+\beta_{1} \mathrm{BS}_{i t}+\beta_{2} \mathrm{BI}_{i t}+\beta_{3} \mathrm{BP}_{i t}+\beta_{5} \\
\mathrm{SF}_{i t}+\mathrm{e}_{i t}-(3)
\end{gathered}
$$

Where, for sample firm $\mathrm{i}$ and year $\mathrm{t}$, Financial Risk (FR), Operating Risk (OR), Market Risk (MR), Board Structure (BS), Board Independence (BI), Board Procedures (BP), Size of the firm (SF-log size of the Assets), $\varepsilon$-Error term

\section{Results and Discussion}

Table 1 presents descriptive statistics on corporate risk and corporate governance variables. As shown in the table, the mean of the ratio of total debt to total 
assets that represents the financial risk is 0.581 . It shows that, on average, for each unit of the total assets of the sample firms, they have almost 0.5 units of longterm deb. The range is between 0.0609 and 4.914 and the standard deviation is 0.545 . The mean operating risk is 0.739 with a standard deviation of 0.628 . This higher mean value of operating risk which measured by total assets to sales represents the firm use 0.7 units of assets to generate 1 unit of sale. The risk is expected to increase as this ratio increases (Platt \& Platt, 2012). The mean value of market risk is 0.9108 which represents a higher average risk of sample firms. If turning to the descriptive of governance variables the mean value of the board structure was 0.925 and minimum and the maximum value was 0 and 1 respectively. The higher mean value represents that the sample firms were comprised of the well-structured board with executive and non-executive directors. The mean value of Board Independence is 0.632 which indicates an average level of independence of boards. Finally, the mean value of Board Procedures (BP) is 0.365 shows that the sample firms have the minimum level of compliance with the required board procedures.

Table 01- Descriptive Statistics

\begin{tabular}{cccccc}
\hline & Minimum & Maximum & Mean & Std. Deviation & Skewness \\
\hline FR & 0.060 & 4.914 & 0.581 & 0.545 & 4.917 \\
OR & 0.000 & 3.759 & 0.739 & 0.628 & 1.897 \\
MR & -16.186 & 18.415 & 0.910 & 1.881 & 0.604 \\
BS & 0.000 & 1.000 & 0.925 & 0.178 & -1.970 \\
BI & 0.000 & 1.000 & 0.632 & 0.181 & -0.496 \\
BP & 0.000 & 1.000 & 0.365 & 0.186 & 0.713 \\
SF & 7.416 & 10.214 & 9.224 & 0.548 & -0.992 \\
\multicolumn{5}{l}{ Financial Risk (FR), Operating Risk (OR), Market Risk (MR), Board Structure (BS), Board } \\
Independence (BI), Board Procedure (BP), Size of the firm (SF) \\
Ceveloped by author, 2019
\end{tabular}

With perusal of the results presented in Table 2, the compliance level of Board Independence is negative correlates with finance risk $(r=-0.134)$. This relation is statistically significant at $0.05(\mathrm{p}<0.05)$. It means firms' increase the Board Independence shows a lower financial risk at the strength of 13 percent. Similarly, the compliance level of Board Structure also negatively correlates with finance risk $(\mathrm{r}=-0.080)$. But, this relationship is not significant at any confidence level. Board procedure is negatively and significantly correlated with the financial risk $(r=-0.228$, $\mathrm{p}<0.01)$. In the same way, the operating risk and all three governance variables were negatively and significantly correlated with each other. The correlation between market risk and the governance variables is negative but not significant at any confidence level. Therefore this result suggests that higher compliance with corporate governance would lead to lower corporate risk for the company. Moreover, these results confirm the findings of prior studies such as those of Mathew (2013), Daily and Dolton (1994) Rosenstein and Wyatt (1990) and Coles et al. (2001). As regards the control variable, the company size is negatively associated with corporate risk. This result is consistent with the results of Chan and Lee (1993). 
The highest variance inflation factor (VIF) value of 1.343 suggests that collinearity among variables is very low, indicating that there is no chance of a multicollinearity issue. This argument was reinforced by the tolerance values as well. The tolerance values of all the variables were greater than of 0.744 . Furthermore when carrying out the regression analyses on the three dependent variables BreuschPagan test was performed and it was found that heteroscedasticity is not present in the data.

Table 02 - Correlation Matrix for Governance Variables and corporate Risk

\begin{tabular}{|c|c|c|c|c|c|c|c|}
\hline & FR & OPER & MR & $\mathrm{BS}$ & BI & $\mathrm{BP}$ & ALS \\
\hline FR & 1 & & & & & & \\
\hline OR & $0.156^{* *}$ & 1 & & & & & \\
\hline MR & $-0.367^{* *}$ & 0.036 & 1 & & & & \\
\hline BS & -0.080 & $-0.011^{*}$ & -0.030 & 1 & & & \\
\hline BI & $-0.134^{*}$ & $-0.262^{*}$ & -0.054 & $0.113^{*}$ & 1 & & \\
\hline BP & $-0.228^{* *}$ & $-0.140^{*}$ & -0.042 & $0.345^{* *}$ & $0.318^{* *}$ & 1 & \\
\hline $\mathrm{SF}$ & $-0.131^{*}$ & -0.074 & $-0.233^{* *}$ & 0.095 & $0.182^{* *}$ & $0.317^{* *}$ & 1 \\
\hline \multicolumn{4}{|c|}{ Tolerance } & 0.881 & 0.892 & 0.744 & 0.892 \\
\hline \multicolumn{4}{|c|}{ VIF } & 1.135 & 1.121 & 1.343 & 1.121 \\
\hline
\end{tabular}

Note $-* *$ Correlation is significant at the 0.01 level (2-tailed). ${ }^{*}$ Correlation is significant at the 0.05 level (2-tailed).

Source: Developed by author, 2019

The results of the independent sample ttests which presented in Table 3 show that there were negative and significant mean differences existed between governance variables of the distress and non-distress companies. Therefore these results statistically confirmed that the level of compliance of corporate governance of distress companies is significantly lower than the non-distress companies in Sri Lanka. In respect of Board Independence (BI), the lower proportion of independent director's representation on their board in distress firms has highly contributed towards significant difference between distress and non-distress firms. The lower compliance level of Board Procedure (BP) in distress companies is result of particularly none of the distress companies have nomination committee to make recommendation to the board on all new appointments and very few distress companies have a system to evaluate the annual board performances, executive directors and CEO. The index scores of all these governance variables was therefore significantly lower in distress companies compared to non-distress companies and accepts the first hypothesis.

Table 4 reports the regression results from the model specified in Equations 01. It used to evaluate the impact of board practices of corporate governance on the financial risk (FR) of the firm. The Hausman test was employed to select the appropriate specification between $\mathrm{FE}$ model and RE model. The specification tests concluded $(p<0.05)$ that FE model was the best model to interpret the association between corporate governance on the financial risk. The predictive power of the FE model $\left(\mathrm{R}^{2}\right)$ is $14 \%$. It means that the explanatory variables in the model explain $14 \%$ variation in the dependent variable. The 
significance of the F-statistic reported in Table 4 implies that the explanatory variables jointly and significantly explain the variations in the dependent variable. Furthermore Table 4 indicates that Board independence and Board procedure were negatively and significantly relates to the financial risk (BI -0.8854, and BP $0.7192, \mathrm{p}<0.05)$. This implies that higher compliance with the Board independence and Bard procedure lead to reduced financial risk. However there was no significant relationship found between Board structure and financial risk. Furthermore, this model has highlighted that the size of the firm as the control variable is statistically insignificant for the financial risk of the firm. However, the relationship was negative.

Table 03 - Corporate Governance Practices of Distress and Non-distress Companies

\begin{tabular}{cccccc}
\hline Variables & Mean-DC & Mean -NDC & Mean Difference & \multicolumn{1}{c}{ t } & \multicolumn{1}{c}{ Sig. } \\
\hline BS & $89.68 \%$ & $95.31 \%$ & $-5.62 \% * *$ & -2.845 & 0.005 \\
BI & $71.25 \%$ & $88.94 \%$ & $-14.84 \% * *$ & -8.017 & 0.000 \\
BP & $26.25 \%$ & $49.24 \%$ & $-20.62 \% * *$ & -11.905 & 0.000
\end{tabular}

Level of significance: $* * 5 \%$ level (based on the 'p-value' of t-statistics) Distress Companies (DC), Non-Distress Companies (NDC)

Source: Developed by author, 2019

Table 04 - Regression Results of Model I

\begin{tabular}{cclcc}
\hline Model I -FR & Coefficients & Std. Error & $\mathbf{t}$ & P (Sig.) \\
\hline BS & -0.0305 & 0.2393 & -0.13 & 0.898 \\
BI & -0.8854 & 0.1419 & -6.24 & 0.000 \\
BP & -0.7192 & 0.1375 & -5.23 & 0.000 \\
SF & -0.0975 & 0.2305 & -0.42 & 0.673 \\
Constant & 8.6571 & 1.2737 & 6.80 & 0.000 \\
R $^{2}$ & 0.1467 & & & \\
F-test & & & & \\
$\chi^{2}$ & 10.83 & & & \\
Prob. & 0.000 & & & \\
Hausman test & & & & \\
$\chi^{2}$ & 29.59 & Observations & 320 & \\
Prob. & 0.000 & No. of groups & 64 & \\
\hline
\end{tabular}

Source: Developed by author, 2019

The second model examines the impact of board practices of corporate governance on the operating risk of the firm. As shown in Table 05, the study has been estimated FE model for proxy of operating risk, following the required diagnostic test. To be exact Hausman test concluded $(\mathrm{p}<0.05)$ that FE model was the best model to interpret the association between corporate governance and the operating risk. The predictive power of the model $\left(\mathrm{R}^{2}\right)$ is $15 \%$ and F-statistic reported a significant value of $11.47(\mathrm{p}<$ 0.05 ). The result of Table 5 shows that board independence is statistically significant with a coefficient ( $\mathrm{p}$-value) of $-0.4519(0.000)$, suggesting that there is a negative relationship between board independence and operating risk of the firm. Board structure and board Kelaniya Journal of Management | 2020 | Vol. 09 | Issue 02 | Page 32 
procedures reported a negative relationship with the operating risk of the firm. However, it is not statistically significant for any confidence $(1 \%$ and
5\%) level. Concerning the control variable size of the firm is statistically insignificant towards firms' operating risk.

Table 05 - Regression Results of Model II

\begin{tabular}{|c|c|c|c|c|}
\hline \multirow[b]{2}{*}{ Model II -OR } & \multicolumn{4}{|c|}{ Fixed Effects } \\
\hline & Coefficients & Std. Error & $\mathbf{t}$ & P (Sig.) \\
\hline $\mathrm{BS}$ & -0.0735 & 0.1266 & -0.58 & 0.562 \\
\hline $\mathrm{BI}$ & -0.4519 & 0.0751 & -6.02 & 0.000 \\
\hline BP & -0.0045 & 0.1455 & -0.03 & 0.975 \\
\hline SF & -0.0503 & 0.1220 & -0.41 & 0.680 \\
\hline Constant & 4.9898 & 0.6741 & 7.40 & 0.000 \\
\hline $\mathrm{R}^{2}$ & 0.1541 & & & \\
\hline \multicolumn{5}{|l|}{ F-test } \\
\hline$\chi^{2}$ & 11.47 & & & \\
\hline Prob. & 0.000 & & & \\
\hline \multicolumn{5}{|l|}{ Hausman test } \\
\hline$\chi^{2}$ & 54.02 & Observations & 320 & \\
\hline Prob. & 0.000 & No. of groups & 64 & \\
\hline
\end{tabular}

Source: Developed by author, 2019

The third regression model examines the association between the specific corporate governance attributes and market risk of the firm. As depicted in the Table 06, FE model was used to estimate the relationship between the governance and risk variables of the model. The predictive power of the model (R2) is only $18 \%$. However the F statistics reported a significant value of $3.79(\mathrm{p}<0.05)$. The result of the regression represented that there is a negative relationship between board structure, board independence and board procedures with the market risk of the firm. However only the board independence presented a significant relationship with the market risk.

\section{Conclusion}

The objective of this study was to examine the impact of corporate governance disclosures on Corporate Risk of listed companies in Sri Lanka. The study was based on secondary data.
64 listed companies were selected from 2014 to 2018. The Board structure, Board Independence and Board procedures were considered as independent variables, whereas, corporate risk as to the dependent variable. The corporate risk was represented the financial risk, operating risk and market risk faced by the listed companies. Since the data in panel nature consisting of both time series and cross-sectional data, linear panel regression was used to establish the relationship between the board specific attributes of corporate governance and corporate risk.

As per the findings from the descriptive statistic ensure that companies listed in CSE are compliance with the corporate governance requirement is at a moderate level. The correlation analysis, represents all independent variables are negatively related to corporate risk. Board independence revealed a significant negative relationship with financial risk and operating risk. 
Table 06 - Model III

\begin{tabular}{cclcc}
\hline & & \multicolumn{2}{c}{ Fixed Effects } & \\
Model III -MR & Coefficients & Std. Error & t & P (Sig.) \\
\hline BS & -0.5684 & 0.7802 & -0.73 & 0.467 \\
BI & -2.6481 & 0.8965 & -2.95 & 0.003 \\
BP & -0.6019 & 0.7516 & -0.80 & 0.424 \\
SF & 1.2682 & 0.4626 & 2.74 & 0.007 \\
Constant & -9.6689 & 4.1519 & -2.33 & 0.021 \\
R $^{2}$ & 0.1853 & & & \\
F-test & & & & \\
$\chi^{2}$ & 3.79 & & & \\
Prob. & 0.0051 & & & \\
Hausman test & & & & \\
$\chi^{2}$ & 43.80 & Observations & 320 & \\
Prob. & 0.000 & No. of groups & 64 & \\
\hline
\end{tabular}

Source: Developed by author, 2019

Further the results of the independent sample t-tests statistically confirmed that the index scores of corporate governance of distress companies is significantly lower than the non-distress companies. Based on this comparative analysis of each governance aspects, the study identified some important weaken practices in distress companies compared to the non-distress companies. They were lack of independent non-executive directors on boards; a lack of independent members on board subcommittees; insufficient performance evaluation of directors; inactive functioning of nomination committees; the failure to conduct annual performance evaluations of non-executive directors; a lack of attention paid to maintaining written codes of conduct and ethics for directors.

The findings of the regression results revealed that there was a significant negative relationship existed between the board independence and corporate risk. Therefore H3, which hypothesized, companies with higher corporate governance index scores of board independence are likely to have lower corporate risk is accepted. These findings are consistent with Byrd and Hickman
(1992), Rosenstein and Wyatt (1990) and Coles et al. (2001). Bathala and Rao (1995) and Rediker and Seth (1995) suggested that the independent directors play an important role in effective corporate governance, especially in terms of decision-making and control function. Therefore, the argument that has been advanced in this study is, if the entity can improve the independent directors' representations and their participation in board activities, it leads to reduce the uncertainty with their effective decisions. In this light, the researcher recommends to increase the number of independent directors' representation in the board to persuade the proper management of corporate risk. Finally, the empirical findings of this study provides vital information for policymakers, corporate governance monitoring agencies and company directors who are ultimately responsible to implement best practices in their companies.

The theoretical perspective of the study supports the argument put forward by agency theory, that corporate governance is a mechanism created to monitor the management, minimizes the problems that may be caused due to the principal- 
agent relationship and ensures maximization of shareholders wealth by resolving and minimizing the risks faced by the firms at different levels. However, the study is subject to a few limitations, such as disregarding the industry-specific factors and economic conditions and scope of the current study was limited only to the listed companies in Sri Lanka. Furthermore the results of the study may be biased either because of unobserved heterogeneity, or because of the presence of dynamic endogeneity. Dynamic endogeneity arises because observable governance structures are likely to be determined by past realizations of performance, or past shocks to performance. The study also recommends that other variables may be identified and analyzed towards their impact on corporate risk. The research results revealed an $\mathrm{R}^{2}$ value of less than $20 \%$, suggesting that there could be other variables influencing the remaining $80 \%$ of the dependent variable variance. Additional analytical models and techniques may also be used to analyze factors that have an impact on corporate risk so that they can be analyzed from different perspectives for future researches.

\section{References}

Archer, D. (2002), Creating a risk management framework: Seven steps to promoting risk awareness across all level of an organization. CMA Management. 76, 16-19.

Balasubramanian, N., Black, B. S. and Khanna, V. (2009), 'Firm-Level Corporate Governance in Emerging Markets: A Case Study of India', University of Texas Law School Law and Economics Research Paper No. 87.

Balasubramanian, N., Black, B. S. and Khanna, V. (2010), 'The Relation between Firm-Level Corporation
Governance and Market Value: A Study of India', University of Texas Law School Law and Economics Research Paper No. 177.

Ballou, B. (2005), A building-block approach for implementing COSO's enterprise risk management- integrated framework. Management Accounting, 6, 1-10.

Battaglia F., Gallo A., Graziano A.E. (2014) Strong Boards, Risk Committee and Bank Performance: Evidence from India and China. In: Boubaker S., Nguyen D. (Eds) Corporate Governance in Emerging Markets. CSR, Sustainability, Ethics \& Governance. Springer, Berlin, Heidelberg (pp 79-105). https://doi.org/10.1007/978-3-642-44955 0_4

Bathala, C. T., Rao, R. P. (1995). The determinants of board composition: An agency theory perspective. Management and Decision Economics. 16(1), 59-69 https://doi.org/10.1002/mde.4090160108

Beasley, M. S., Clune, R., and D. R. Hermanson (2005), Enterprise Risk Management: An Empirical Analysis of Factors Associated with the Extent of Implementation, Journal of Accounting and Public Policy, 24, 512-531.

Berle, A. and Means, G. (1932), 'The Modern Corporation and Private Property, Harcourt, Brace \& World. New York'. Retrieved from http://en.wikipe dia.org/wiki/The Modern Corporation and Private Property

Baldwin C., Scott M. (1983), 'The Resolution of Claims in Financial Distress: The case of Massey Ferguson', Retrieved from http://onlinelibrary.wiley.com/doi/10.111 1/j.1540-6261.198 3.tb02258.x /abstract

Byrd, J. and Hickman, K. (1992). Do Outside Directors Monitor Managers: 
Evidence from Takeover Bids? Journal of Financial Economics, 32, 195-221.

Cadbury, A. (1992). Report of the committee on the financial aspects of corporate governance, Cadbury Report. London: Gee Publishing London.

Carcello, J. V. (2005) "Factors Associated with U.S. Public Companies' Investment in Internal Auditing" Accounting Horozone, 19 (2), 69-84. https://doi.org/10.2308/acch.2005.19.2.69

Chan, K. C., and Chen, N. F. (1991). Structural and Return Characteristics of Small and Large Firms. The Journal of Finance, 10(2), 1467 -1484.

Chen, k. and Lee, C. W. J. (1993). Financial Ratios and Corporate Endurance: Case of the Oil and Gas Industry. Contemporary Accounting Research Spring, 667-694.

Coles, J.W., McWilliams, V.B. and Sen, N. (2001). An Examination of the Relationship of Governance Mechanisms to Performance. Journal of Management, 27(5), 23-50. https://doi.org/10.1177/01492063010270 0102

Daelen, M. V. and Elst, C. V. D. (2010). Risk management and corporate governance Interconnections in Law, Accounting and Tax. Edward Elgar Publishing Limited, UK.

Daily, C. M., and Dalton D. R. (1994). Corporate governance and the bankrupt firm: An empirical assessment. Strategic Management Journal, 15(8), 643-654. https://doi.org/10.1002/smj.4250150806

Knight, K.W. (2006), Risk management a journey not a destination. Paper presented at the Executive Meeting 2006 in Brazil

Lajili, k, (2009), Corporate Risk Disclosure and Corporate Governance.
Doherty, N.A. (2000), Integrated risk management: Techniques and strategies for managing corporate risk. New York: McGraw-Hill, Inc.

Elloumi, F., and. Gueyle, P.J (2001), 'Financial Distress and Corporate Governance: An empirical Analysis', Journal of Corporate Governance,1(1), 15-23.

Fama, E.F. and K.R. French, (1997), Industry Costs of Equity. Journal of Financial Economics, 93(2), 153-194. https://EconPapers.repec.org/RePEc:eee:j finec:v:43:y:1997:i:2:p:153-193

Fama, E.F. and K.R. French, (1992). The Cross- Section of Expected stock Returns. Journal of Financial, 02, 427465. doi: $10.2307 / 2329112$

Hausman, J. A. (1978). Specification tests in econometrics. Econometrics, 46(6), 1251-1271. https://doi.org/10.2307/1913827

Hsiao, C. (2007). Panel data analysis Advantages and challenges Test, 16, 122. https://doi.org/10.1007/s11749-0070046-x

Jensen, M.C., and Meckling, H.W. (1996). Theory of the Firm: Managerial Behavior, Agency Costs, and Ownership Structure', Journal of Financial Economics. 3(.4), 305-360.

Johl, S., Kaur, S., \& Cooper, B. (2015). Board Characteristics and Firm Performance: Evidence from Malaysian Public Listed Firms. Journal of Economics, Business, and Management. 3(2), 239-243. http://dx.doi.org/10.1016/j.jbusres

Journal of Risk and Financial Management, 2, 94-117. https://doi.org/10.3390/jrfm2010094

$\begin{array}{lcc}\text { Lakshan, } & \text { A.M.I. and } & \text { Wijekoon, } \\ \text { W.M.H.N., } & (2012), & \text { Corporate }\end{array}$ Kelaniya Journal of Management | 2020 | Vol. 09 | Issue 02 | Page 36 
governance and corporate failure. Procedia Economics and Finance, 2, 191 $-198$.

Lee, T. S. and Yeh, Y. H. (2004), 'Corporate Governance and Financial Distress: Evidence from Taiwan', Journal of Corporate Governance, 12 (03), $378-300$.

Lotfi, S., \& Mohammadi, A. (2014). The Relationship between Ownership Structure and Risk Management: Evidence from Iran. International Journal of Academic Research in Business and Social Sciences, 4(2), 5362. Retrieved fromhttps://EconPapers.repec.org/RePEc: hur:ijarbs:v:4:y:2014:i:2:p:53-62

Manawaduge, A. S. P. G. (2012), 'Corporate Governance Practices and their Impacts on Corporate Performance in an Emerging Market: the case of Sri Lanka'. Retrieved from http://ro.uow.edu.au/cgi/viewcontent.cgi? article $=4678 \&$ cont ext $=$ theses

Mathew, S. (2013). Board Composition and Risk-taking in UK firms.

McNulty T., Florackis C., Ormond P.(2012), Corporate Governance and Risk: A Study of Board Structure and Process. Certified Accountants Educational Trust. London

Meier, R.L. (2000), Integrating enterprise-wide risk management concepts into industrial technology curricula. Journal of Industrial Technology, 16(4), 1-15.

Merna, T. and Al-Thani, F. (2011), Corporate Risk Management, 2nd Ed., Jhon Wiley and Sons Ltd.

Miglani, S., Ahmed, K., Henry, D. (2010), 'Corporate Governance and Financial Distress: Evidence from Australia' Paper presented at the
Accounting and Finance Association of Australia and New Zealand (AFAANZ) Conference, Christchurch, New Zealand, $1-55$.

Miglani, Seema \& Ahmed, Kamran \& Henry, Darren, 2015. "Voluntary corporate governance structure and financial distress: Evidence from Australia," Journal of Contemporary Accounting and Economics, 11(1), 18-30. DOI: $10.1016 /$ j.jcae.2014.12.005

Minton, B., J. Taillard, and R. Williamson. 2010. "Board Composition, Risk Taking andValue: Evidence from Financial Firms." Mimeo. Ohio State University

Mitton, T., (2002), A cross-firm analysis of the impact of corporate governance on the East Asian financial crisis. Journal of Financial Economics, 64(2), 215-241. https://EconPapers.repec.org/RePEc:eee:j finec:v:64:y:2002:i:2:p:215-241

Nahar, S., Azim, M., \& Jubb, C. (2016). The determinants of risk disclosure by banking institutions: Evidence from Bangladesh. Asian Review of Accounting, 24(4), 426-444. doi: 10.1108/ARA-072014-0075

Nam, S. W. and Nam, C. (2004), Corporate Governance in Asia, Recent Evidence from Indonesia, Republic of Korea, Malaysia, and Thailand, Asian Development Bank.

Nguyen, P. (2011). Corporate governance and risk-taking: Evidence from Japanese firms. Pacific-Basin Finance Journal, 19(3): 278-297.

http://dx.doi.org/10.2139/ssrn.1550709

OECD (2014), Risk Management and Corporate Governance, Corporate Governance, OECD Publishing. Retrieved from http://dx.doi.org/10.1787/97892642 08636-en. 
Platt, H., \& Platt, M. (2012). Corporate board attributes \& bankruptcy. Journal of Business Research, Retrieved from. https://doi.org/10.1016/j.jbusres.2011.08. 003

Rabelo, F. \& Vasconcelos, F. (2002). Corporate governance in Brazil. Journal of Business Ethics. 37(3): 321-335. https://doi.org/10.1023/A:101524930079 4

Rediker, J. K., Seth, A. (1995). Boards of directors and substitution effects of alternative governance mechanisms. Strategic Management Jounal, 16(2), 8599.https://doi.org/10.1002/smj.42501602 02

Rosen, D., \& Zenios, S.A. (2001), Enterprise-wide asset and liability management: issues, institutions, and models. Nicosia, Cyprus: HERMES Center on Computational Finance \& Management, University of Cyprus.

Rosenstein, S. and Wyatt, J.C. (1990). Outside Directors, Board Effectiveness and Shareholder Wealth. Journal of Financial Economics, 26: 175-91. https://EconPapers.repec.org/RePEc:eee:j finec:v:26:y:1990:i:2:p:175-191

Sah, R., \& Stiglitz, J. (1991). The quality of managers in centralized versus decentralized organizations. Quarterly Journal of Economics, 289-295. https://doi.org/10.2307/2937917

Sameera, T.K.G., Wijesena, E.P.I.S., (2018). The impact of board structure of corporate governance on credit risk: special reference to the banks listed in Colombo Stock Exchange in Sri Lanka. International Journal of Accounting \& Business Finance, 04(2), 1-10.

Sheedy, E. (2010). Agency Risk: The Forgotten Element in Financial Risk Management. Economic Papers: A journal of applied economics and policy, 18(4), 80-91. doi.org/10.1111/j.175941.1999.tb01164.

Spira, L. and Bender, R. (2004). Compare and contrast: perspectives on board committees, Corporate Governance: An International Review, 12(4), 489-499. https://doi.org/10.1111/j.1467-

8683.2004.00389.x

Terry, M., Chris, F. \& Phillip, O. (2012) "Corporate Governance and Risk: A Study of Board Structure and Process", Research report 129, ACCA.

Tonello, M (2007), Emerging Governance Practices in Enterprise Risk Management. Retrieved from http://dx.doi.org/10.2139/ssrn.963221 on 25th July 2018.

Vafeas, N. (2003), 'Length of Board Tenure and Outside Director Independence', Journal of Business Finance and Accounting, 30: 1043-64. https://doi.org/10.1111/1468-5957.05525 


\section{Appendices}

\section{Appendix A}

\begin{tabular}{|c|l|}
\hline \multicolumn{1}{|l|}{ Corporate Governance Variables and Sub-indices } \\
\hline \multicolumn{1}{|c|}{ (1) Board Structure } \\
\hline 1 & Board Composition \\
& $\begin{array}{l}\text { The board consists of two or one-third of the total number of Directors, whichever is } \\
\text { higher of Non-Executive Directors. }\end{array}$ \\
\hline & CEO Duality \\
\hline 2 & CEO is not the chairman of the board \\
\hline \multicolumn{2}{|l|}{ (2) Board Independence } \\
\hline 3 & Board has Independent Directors \\
\hline 4 & Majority of non-executive directors are independent \\
\hline 5 & Selection of non-executive directors is done by the board or nomination committee \\
\hline & (3) Board Procedure \\
\hline & Board Meetings \\
\hline 6 & The firm held four or more regular board meetings per year \\
\hline & Appointments of Board \\
\hline 7 & Nomination Committee exits \\
\hline 8 & Nomination Committee consists of exclusively by non-executive directors \\
\hline 9 & Nomination Committee chaired by an independent director \\
\hline 10 & Appointments to the board are made only through the nomination committee \\
\hline 11 & The firm has formal and transparent procedures for the election of directors \\
\hline 12 & The board consist of members with sufficient financial acumen \\
\hline & Appraisal of Performance \\
\hline 13 & The firm has a system to evaluate the annual board performance \\
\hline 14 & The firm has a system to evaluate CEO \\
\hline 15 & The firm has a system to evaluate other executives directors \\
\hline & Supply of Information \\
\hline 16 & The firm has a provision of appropriate and timely information to board \\
\hline 17 & Board receives materials at least 7 days in advance \\
\hline & Code of Business Conduct \& Ethics \\
\hline 18 & The firm has a code of ethics for directors \\
\hline & \\
\hline
\end{tabular}

